\title{
THE OTTOMANS AND WESTERN EUROPEANS DURING THE MERCANTILIST TIMES: NEUTRALITY, COMPETITION AND CONFLICT
}

\author{
Mehmet Bulut*
}

\begin{abstract}
This paper seeks to explore the fundamental objectives and differences between the economic outlooks and policies of the Ottomans and western capitalist nations in the early modern period. As western European powers expanded their commercial trade worldwide, the Ottoman Empire simultaneously extended its influence east and west. However, the objectives, priorities and policies shaping both expansions were strikingly different. The Ottomans encouraged diverse commercial activities and traded with both Muslim and non-Muslim merchants within and beyond the Empire, who only needed to comply to several capitulations enforced by Ottoman authorities but were otherwise fully encouraged to enter the Ottoman market. The principal European mercantile communities were predominantly Dutch, British and French, and were not differentiated by political and economic policies. Their economic activities were rather supportive of the Ottoman economic priorities. However, the serious competition and consequently conflicts increased among western mercantilist nations in their commercial and economic activities in the territories of the Empire. This paper concludes that while Ottoman trade activities largely focused largely on human welfare, western mercantilists instead concentrated on profitability with the aim of "homo-economicus".
\end{abstract}

Keywords: Ottoman, Europe, mercantilism, trade, competition, conflict

\section{Introduction}

Despite the existing similarities, the nature of the economic objectives of the Ottomans and western capitalist national states clearly differ in the early modern times. As the followers of the civilization of Islam and classical empires, the economic policies of the Ottomans were geared to ensuring citizens' subsistence, provision of needs of major population centers, collection of taxes and maintaining of trade freedom. The then prevailing social balance and stability explains the Ottomans' economic vision. However, commercialization, economic growth and profit explains the economic priorities of the mercantilist European nations whose objectives of their economic policies was to employ the power of the state to further promote trade and economic growth.

And while the oceanic trade increased from the beginning of the sixteenth century, this new trade route was not a real trade alternative for Europeans with the East. In addition to western European nations' mercantilist and commercial interests, the flexible economic policies of the Ottomans and their privileges (capitulations) towards the rising Western trading nations were rather crucial to the trade continuity throughout the Ottoman territories and the Levant. Conflicts, wars and political conditions in the eastern part of the Mediterranean also influenced the commercial activities of Western merchants in the early modern period, and while southern Europeans wore themselves out with a succession of wars, the Dutch, English and French captured much of the Levant trade.

Overall, the Italian and Spanish shipping declined. There was a shortage of timber and the ship design was in fact inferior to the northern European ships, which were generally better built, faster and with lower freight rates. Beginning with the middle of the sixteenth century, the Mediterranean trade began to be penetrated by northwestern European ships that carried supplies of scarce goods to southern Europe, mostly in the form of bulky commodities such as grain, timber and dry fish, but also had luxury commodities such as spices and textile products. Initially, Baltic grain was the major trading item from northern to southern Europe. There was a strong correlation between grain prices in the different region of Europe and its traffic volume. It was a trade in bulk goods for daily use that were exported from the Baltic States, which had large surpluses of several primary products to Western Europe and the Mediterranean.

\footnotetext{
* Mehmet Bulut (PhD), Professor and currently serve as Rector, Istanbul Sabahattin Zaim University, Istanbul, Turkey. Email: mehmet.bulut@izu.edu.tr.
} 
Up until the end of the sixteenth century, the Ottomans enjoyed significant and even increasing profits from spices and silk routes connecting the East to the West. However, this situation began to change when the northern Europeans appeared as active nations in the profitable Far East and Levant trade. Those developments forced the Ottomans to pursue new strategies for maintaining their profit interests from the East-West trade routes. The Ottomans encouraged the newly rising western European nations (France, England and the Dutch) to trade in the Ottoman territories by way of granting them some privileges (capitulations). ${ }^{1}$ They continued to play a crucial role in trade between the East and West following the expansion of European commercial power. Because of their Ottoman privileges however, the northwestern European merchants established a direct, regular and growing trade with the eastern Mediterranean, which represented a new stage for their commercial relations with the Levant and the territories of the Ottoman Empire.

Many studies have addressed the economic and commercial relations between the Ottomans and the Western mercantilist nations. For instance, Dutch trade and shipping to the Ottoman territories have been studied by scholars like Heeringa (1910), Erdbrink (1975), Israel (1989) and Bulut (2001). On the other hand, economic and trading relations between the Ottomans and French have been examined by Masson (1896), Cole (1943), mantran (1990) and Eldem (1999). British-Ottoman relations have been studied by Hanway (1754), Abbot (1920), Wood (1935), Kurat (1953), Davis (1970) and Talbot (2017). Braudel (1972) believes that despite 'the discoveries' and some fundamental changes in the world of the sixteenth and seventeenth centuries, the Northwestern European capitalist nations continued to trade within Ottoman world economy. Wallerstein (1979), argues that as a world empire, the Ottoman Empire came into contact with a capitalist European world economy in the early modern times.

In spite of the importance of the works mentioned above, one needs to acknowledge that they only made evaluations that can best be described as general concerning the relations between the Ottomans and Northwestern European nations and the major contributions driving trade between the Levant and Atlantic regions. They failed clearly highlight critical issues such as the main dynamics, mindsets, objectives and priorities underlying the relations between these two worlds. This current study uses secondary sources but also give due attention to original archival registers both from the Ottomans and west to better understand and analyze the salient goals, mindsets and priorities underlying the relations between these two worlds.

\section{The Expansion of the Ottoman Empire and the Rise of Western Europe}

While the period of the fifteenth century may be described as expansionist for the Ottomans, the end of this century marked Europe's expansion to the west across the Atlantic into the Americas and the East by sea via the Cape of Good Hope to Asia. That marked a turning point for western European nations. ${ }^{2}$ Various factors both internal and external explain the European expansion during this period. One external factor was the Ottoman expansion in both the East and West and also their control of the EastWest trading routes. The West had to find alternative routes to the East. The middle of the fifteenth century was a crucial period to the relations between the Ottoman Empire and the West. The conquest of Constantinople (Istanbul) in $1453^{3}$ marked a new stage for relations between the Ottomans and the Western world. Following the middle of the fifteenth century, the Ottomans, as in the words of William Harborne, "become fearful and terrible to the whole world." Some historians believe that the Ottoman conquest of Istanbul confronted Christendom, when the perception of an Ottoman "identity threat" led the Papacy to issue a series of papal bulls. Those bulls effectively ordered southern Europeans, especially Iberians, to undertake Crusades through another route and to expand outward in order to

\footnotetext{
${ }^{1}$ The first Ottoman grant of trade privileges, or capitulations, to the Genoese in 1352, and subsequently to Venice and Florence, guaranteed the continuation of the grand commerce of these maritime republics with the Levant. The Ottomans extended the same trade privileges to France in 1569, to England in 1580 and to the Dutch Republic in 1612. In those early centuries when the Ottoman sultans represented a superpower in the Mediterranean and the East, they granted such privileges only to those Western nations they judged as friendly.

${ }^{2}$ In his famous chapter on colonies, Adam Smith noted that "the discovery of America and that of a passage to the East Indies by the Cape of Good Hope, are two greatest and most important events recorded in the history of mankind." See A. Smith (1993), An Inquiry into the Nature and Causes of the Wealth of Nations, K. Sutherland (ed.), New York: Oxford University Press, p. 363.

${ }^{3}$ There is a common view that the Battle of Ankara in the beginning of the fifteenth century (1402) postponed the conquest of the capital of the Byzantine Empire, Constantinople (Istanbul), by more than 50 years. The Ottoman central authority was divided among the sons of the Ottoman sultan. A war broke out with Venice in 1423 over Salonica, which lasted until 1440. Meanwhile, the Hungarians crossed the Danube in 1428 and invaded Serbia.

${ }^{4}$ The first English ambassador in the Ottoman Empire in the sixteenth century.
} 
make links with Peter John, the Catholic priest-king, in the "Indies" with whom they forged a Christian alliance and attacked the Muslims from the rear. ${ }^{5}$

Following the conquest of Constantinople, the Ottomans realized the ideal of a universal empire. The conqueror (Fatih), Mehmet II, believed that he was the successor to Byzantine emperors and saw himself as heir to a world empire. His wish was for Istanbul to become the center of the world par excellence. He also believed that introducing this city to the Muslim world would lead to extending his rule over the whole Christian world. He created in his person the prototype of Ottoman sultans who would combine the Islamic, Turkish and Byzantine traditions. It was Mehmet the conqueror who established the new distinctive character and nature of the Ottoman Empire after the middle of the fifteenth century. Thus, the Ottoman state expanded from a regional to a worldwide empire. However, following the conquest of Istanbul, the Ottomans continued to extend their territories to the Balkans and Europe, ${ }^{6}$ and went through rapid expansion under Mehmet II.

The conquest and transformation of Constantinople into Istanbul as well as the consolidation of the Ottoman power in the Balkans placed the Byzantine maritime resources into the hands of the Ottomans. The Ottoman extension continued into Europe during the second half of the fifteenth century; however, turned to the East at the beginning of the sixteenth century. There might have been some good reasons for the Ottomans to turn to the East. In particular, the Portuguese threat to the holy places of Islam (Mecca and Medina) and their connections and coalitions with some regional powers against the Ottomans explain the decision of the Ottoman rulers to turn to the East in the beginning of the sixteenth century. ${ }^{7}$ There were three major Muslim powers in the region: the Safavids (Persian empire), the Mamluks and the Ottomans. In 1514, the Ottomans won the Çaldiran war against the Safavids and three years won the Battle of Cairo (Ridaniye war) against the Mamluks in 1517. The Ottomans' conquest of Egypt meant inclusion of Syria, Egypt, Sudan, Arabia, Anatolia and the Balkans.

Accordingly, the Ottomans now controlled Mecca and Medina, and at the same time, moved the Islamic Caliphate from Cairo to Istanbul. Thus, the Ottomans became responsible for the world of Islam and advocate of the Muslim interests, not only those in the Balkans, Anatolia and Africa, but also in Asia, the Indian Ocean and the Far East. ${ }^{8}$ The Ottomans' attempt to establish undivided rule in the Balkans and south Europe brought them into conflict with Hungary and Venice. Starting from that period, the papacy in the West sought to lead the entire Europe against the Ottomans. The papacy's efforts caused the Ottomans to pursue a new strategy of developing their relations in the following centuries with the rising Atlantic nations including the French, English and Dutch.

However, the conquest of the Balkans opened the way for a two-century-long struggle against the powers of Europe. In this war, the Ottomans were primarily allied with France against their principal enemies, the Hapsburg Empire in Spain. In the early days of the Ottoman expansion, the dominant naval powers in the Mediterranean were Venice and Genoa. However, the wars in central Europe were accompanied by an equally vast Ottoman- Hapsburg struggle for control of the Mediterranean. Together with the Kings, the Pope strongly supported the project of European exploration. In 1493, the Pope had issued a bill allocating trade in the Americas to Spain and trade in Asia to Portugal. In this division of the world, the Portuguese were given sugar, spices and slave trades. But what the English [and Dutch] envied most was the gold and silver the Spanish discovered in America." Europe was enriched immensely from the consequent emergence of Atlantic economy and capture of trade with Asia. The Ottomans had to consider European efforts to divert international trade from the Mediterranean to the Atlantic routes in the sixteenth and seventeenth centuries. By 1507, the Portuguese established a series of bases in the Indian Ocean, which cut off trade to the Red Sea and the Mediterranean. However, after 1517, the Ottomans established their own bases in Asia and Africa. The

\footnotetext{
5 J. M. Hobson (2004), The Eastern Origin of Western Civilisation, Cambridge.

${ }^{6}$ The Ottomans ruled these territories by right of conquest, not inheritance. The capture of Constantinople in 1453 was the basis for the sultan's claim to be the rightful ruler of all the territories that had once been part of the Eastern Roman (Byzantine) Empire. In 1480, the empire included territories in the Balkans and Anatolia. By 1580, the empire included most of Hungary, all of Anatolia and the Balkans, Syria, Egypt, Iraq, Rhodes, Cyprus, Azerbaijan and parts of North Africa. The empire's peoples included Turks, Arabs, Greeks and Slavs, whose religions included Islam, Judaism and many forms of Christianity. Modern views of Ottoman identity struggle to label this mixture of peoples.

${ }_{7}^{7}$ For more information, see C. Casale (2010), The Ottoman Age of Exploration, New York: Oxford University Press.

${ }^{8}$ During the half-century reign of Sultan Suleiman the Magnificent, "the Lawgiver," the Ottomans were seen as the lords of the holy cities of the Hijaz (Mecca and Medina) (in addition to Jerusalem) and as the only great Muslim power with a true maritime reach. They also periodically boasted that they alone possessed territories in all of the "seven climes" of traditional Islamic geography.
} 
Portuguese and Ottomans established a frontier in the Indian Ocean based upon their respective interests.

It can be said that trading and economic system of the Americas in the early modern period were a European creation. However, the situation in Asia and especially in the Levant was entirely different. There, Europeans participates in the trading and economic systems of the region. France established both diplomatic and commercial relations with the Ottoman Empire early in the sixteenth century. In 1536, French merchants gained a capitulation from the Ottomans. With it, the king of France exercised jurisdiction over the Western merchants in the Levant, which obliged them to enter and do business in the territories of the Ottoman Empire only under the French flag and representation of French ambassador and consuls. French representatives in the Ottoman Empire had the privilege of collecting consular fees on all goods brought into the Ottoman domains. In the second half of the century, the English entered the Levant and France was confronted with a strong aggressive rival challenging its diplomatic and commercial position in the very territories of the Ottoman Empire.

Formal commercial relations between the English and Ottoman Empires began in 1580, when Sultan Murad III granted capitulations to this Atlantic nation. However, the regular trade between England and the Levant had been in the earliest times on the hands of Italian merchants. Hakluyt reports several visits of English merchants to the Levant between 1511-1534, 1550 and 1553 . $^{9}$ Prior to gaining privileged capitulations, the English merchants traded under French protection in the Levant. During the reign of Queen Elizabeth however, they organized their business under the monopolistic organization of Levant Company. ${ }^{10}$ Traditionally, the French maritime trade was concentrated largely in the Mediterranean rather than in the Atlantic. However, Iin 1569, the French gained capitulations from the Ottoman Sultan, who granted permission to nations, with no treaty of their own, to trade under the same conditions, when flying the French flag. ${ }^{11}$ Because of those privileges, the Ottoman sultan granted the right to the French to protect the harbi $i^{12}$ merchants in the Levant. In 1598, France extended those privileges to the Dutch; hence, the Dutch merchants obtained formal permission from King Henry IV to trade in Ottoman ports under the French flag. ${ }^{13}$ However, before this time, Dutch merchants already traded under French or English flags in the Ottoman ports. The following statement clearly explains the situation of the Levant for Western Europeans towards the end of the sixteenth century:

In the year 1595 our trade with Turkey had only been in existence about 15 years. Sir Edward Barton was the second ambassador from England to the Turkish Empire and his position was an extremely difficult one... it was necessary for him to protect himself and the English merchants against the intrigues of the French and Venetian Ambassadors, who were very naturally anxious to oust the British competitor for the lucrative trade of the Levant. $^{14}$

\section{Changing Economic Center of the World Economy and Increasing Relations between the Two Worlds}

According to Braudel, the center of the European world economy moved from the Mediterranean to the Atlantic long after the sixteenth century and the rise of the French, British and Dutch as the "modern"

\footnotetext{
${ }^{9}$ R. Hakluyt (1927), The Principal Navigations, Voyages, Traffiques and Discoveries of the English Nation, London, p. 2.

${ }^{10}$ W. Beawes (1792), Lex mercatoria rediviva: or, a complete code of commercial law. Being a general guide to all men in business, London, p. 1039; Sir P. Griffiths (1974), The History of English Chartered Companies, London, pp. 41-56.

${ }^{11}$ Braudel. The Mediterranean and the Mediterranean World in the Age of Philip II, S. Reynolds (trans.), New York, 1972, pp. 625-628; A.

N. Kurat (1953), Türk-Ingiliz Münasebetlerinin Başlangici ve Gelişmesi, Ankara, pp. 305-315.

${ }^{12}$ According to Ottoman Muslim theory, Harbis (foreigners) were those enemy aliens or non-Muslims not protected by treaty who inhabit the Darül-harb, i.e., any part of the world which had not yet become Darül-islam, which was the part of the world that was ruled according to Islamic law (Qur'an). The life and property of a harbi venturing into Muslim lands were completely unprotected by law unless he was given a temporary safe-conduct, eman. He was called müstemin and, in general, his position resembled that of a zimmi (dhimmi), a tax-paying nonMuslim protected by treaty, except that he was not obligated to pay taxes for one year. Should he remain longer than one year, however, he was made a zimmi.

${ }^{13}$ This situation was also explained by Sir Robert Cecil in Heeringa, K. (ed.) (1910), Bronnen tot de Geschiedenis van den Levantschen Handel, (1590-1726), RGP: 9,10,34, The Hague, as follows: "[1599]...The Flemmings merchants doe beginne to trade into these countries, which will clean subvert ours, allthough it be now butt little worth; yet seing ther is no means to prohibit them, I thought it better to take their protection then suffer them to go under the French, whoe ceaseth not to give them all the trouble he can, saying they ought to come under his kinge, and allthough the Grand Signor hath absolutely commanded they shall come under H.M.'s her bannor and noe other, yet with his continual bribing he still troubleth me... and now [1600] last of all the vizrey being changed, with hope to bribe him he beginneth a new sute with me for the sayd Flemmings, alleging they are the king of Spain his subiects and most come under him as other foresteers, whoe are of right belonging to us by a former graunt. Thus, what with his mony and hope these have, that he will turn Turke, he findeth suth freindshipp..." ${ }^{14}$ R. H. G. Rosedale (1904), Queen Elizabeth and Levant Company, London, pp. 41-42.
} 
naval and commercial powers in the West. In the same period, the Ottoman Empire was a "redistributive" power and continued to be important in Europe and the world. ${ }^{15}$ Steensgaard argues that the European consumption of Asian goods in the early modern period increased, and that this was an important development in the pre-industrial economy. He noted that the available information on the Levant trade confirms this claim. He states: "Naturally it is impossible to determine the exact date when the transit trade ceased. Strictly speaking it never did cease and Asian goods were occasionally conveyed to Europe through the Levant well into the seventeenth century."16

In the first half of the seventeenth century, the Ottoman-Atlantic commercial relations in the Levant consisted of trade in both bulky and luxury commodities. While Ottoman exports to western Europe consisted largely of domestic products like raw silk, cotton, mohair yarn, wool, cloth and other textiles, European merchants supplied items such as spice and pepper, certain strategic materials such as lead, tin, steel, copper, saltpeter, swords, gunpowder and grain, and increasingly larger numbers of silver coin to the Empire. However, not all traded goods were produced in Europe or the Empire; all types of Western and Eastern commercial products were traded among merchant communities.

Throughout the seventeenth century, the Dutch and English merchants became more important than Portuguese merchants in the spice trade in the Levant, the Indian Ocean, Malaysia and Indonesia. Merchants from England and the Dutch Republic changed the spice trade routes of the Portuguese and the Venetians in the seventeenth century. ${ }^{17}$ Dutch pepper and fine spices began to arrive in large quantities at Genoa and Leghorn from 1609 onwards. Within a few years, spices, which had been distributed from Aleppo by the Venetians, and from Lisbon by the Genoese, had vanished from the scene. By the middle of the Twelve Years Truce, the Dutch were the undisputed masters of the Mediterranean spice traffic. ${ }^{18}$ The first big Dutch convoy to the Levant, ten heavily armed and manned ships, crammed with spices, which sailed to 'Cyprus, Syria, Palestine and Egypt' in 1609, were equipped with guns, munitions, and additional men, free of charge, by the States General. ${ }^{19}$ In the second decade of the century, Dutch ships reached Istanbul with spices for the most part. ${ }^{20}$

Ömer Talip, a Turkish contemporary observer wrote:

Now the Europeans have learnt to know the whole world; they send their ships everywhere and seize important ports. Formerly the goods of India, Sind and China used to come to Suez, and were distributed by Muslims to all the world. But now these goods are carried on Portuguese, Dutch and English ships to Frangistan [Europe], and are spread all over the world from there. What they do not need themselves they bring to Istanbul and other Islamic lands, and sell it for five times the price, thus earning much money. For this reason, gold and silver are becoming scarce in the lands of Islam. ${ }^{21}$

The above means that the Levant towns which previously exported Asian goods to European markets began to import the same goods from those markets. Pepper and spices were the main products to change direction, indigo followed somewhat later. According to Meilink-Roelofsz, there was a "close connection between the expansion of the United Company's spice monopoly and trade in Mocha."22 For her the price of spices was lower in Mocha than in Europe in the first half of the seventeenth century, which is why most Dutch merchants did not want to sell spices there. But there was a large demand for pepper in Mocha. ${ }^{23}$

\footnotetext{
${ }^{15}$ F. Braudel, The Mediterranean and the Mediterranean World, pp. 1166-1177.

${ }^{16}$ N. Steensgaard (1973), The Asian Trade Revolution of the Seventeenth Century: The East India Companies and the Decline of the Caravan Trade, University of Chicago Press, p. 171.

${ }_{17}$ M. A. Meilink-Roelofsz (1962), Asian Trade and European Influence in the Indonesian Archipelago between 1500 and about 1630 , The Hague, p. 135

18 J. Israel, Dutch Primacy in World Trade, p. 97.

19 J. Israel, Dutch Primacy in World Trade, pp. 97-98. After 1610, the Dutch Republic tried to build up a network for Levant trade and aimed to establish diplomatic relations with the Ottoman sultans in the Levant based on this trade. The main postings were those of a resident ambassador in Istanbul (1612) and the consulates at Aleppo (1613), Larnaca (1613) and Algiers (1616).

${ }^{20} \mathrm{~K}$. Heeringa, Bronnen tot de Geschiedenis van den Levantschen Handel, pp. 102-110.

${ }^{21}$ B. Lewis (1968), The Emergence of Modern Turkey, London, 1968, p. 118.

${ }^{22}$ M. A. Meilink-Roelofsz, Asian Trade and European Influence, pp. 222-226.

${ }^{23}$ M. A. Meilink-Roelofsz, Asian Trade and European Influence, p. 226.
} 
From the middle Ages, the Levant was an important supplier of silk to Europe. Silk was the main trading commodity in the commercial relations between the Ottomans and Europe since the establishment of the Empire. Although Persia was also an important producer of silk in Asia, the Ottomans became the principal silk exporters produced from Persia to the West during its control of silk trade route between the East and West. The term "Ottoman Raw Silk" included the silk produced domestically and from outside of the Empire, such as Persian silk. Chinese and Indian silk did not play a role in this period. However, Persian raw silk was very important in the commercial relations between the Ottomans and Western nations. ${ }^{24}$ In fact, many European merchants who came to Aleppo, Bursa, Istanbul and İzmir bought silk there.

The needs of a nascent silk industry in Europe heightened Aleppo's importance, at least temporarily, as Persian raw silk formed the bulk of the cheap silk available in the world markets until the end of the seventeenth century. ${ }^{25}$ However, the Persians were unable to increase their production and competition for stocks available in Aleppo intensified accordingly. The Venetians had held the unchallenged lead in Aleppo's trade for well over a century, but their position was now threatened by the French, English and Dutch, as new products and types of organizations were introduced for raw silk.

From the middle of the 1620 s, due to the Persians' effort to change the trade route from the East to the West, the commercial activities of the Dutch merchants moved to the Persian Gulf or to Moscow. Thus, in the 1630s, the English and Venetian merchants became more important in the Levant than the Dutch. This however, does not mean that Dutch trade in the Levant totally collapsed between 1620 and 1640 . There was a relative decline between 1625 and 1635 in the Dutch Levant trade, but one cannot claim that this was only a result of the Spanish embargo. Moreover, following the middle of the 1630s, the commercial relations between the Ottomans and the Dutch began to flourish again because the trading of new goods.

Table 1. Western remittances in cash and goods to Aleppo, 1604 and 1613 (Venetian Ducats)

\begin{tabular}{|l|l|l|}
\hline Trading nation & 1604 (Teixeira) & 1613 (Morosini) \\
\hline Venice & $1,250,000$ & 850,000 \\
\hline France & 800,000 & $1,750,000$ \\
\hline England & 300,000 & 250,000 \\
\hline United Provinces & 150,000 & 500,000 \\
\hline
\end{tabular}

Source: J. Israel, Dutch Primacy in World Trade, 99.

There were various reasons for the decline of Aleppo, such as rivalry between the Ottomans and Persians, the appearance of certain difficulties for the Dutch merchants within the Empire, and the rise of İzmir in international trade as the main entrepôt in the Levant. Therefore, with the decline of the silk trade in Aleppo, certain new commercial centers emerged in the Ottoman Empire.

The shift in the silk trade routes away from Aleppo is a discussion topic among historians. According to Masters, in the beginning of the seventeenth century, traders from the Low Countries and England began to look for alternative trading routes for silk. ${ }^{26}$ A domestic reason for this change is the cost of silk transportation to Europe through the Empire: transport costs by camel amounted to " 40 gurush, or about 26 gold ducats per load; when various dues paid en route were added, the costs rose to 122 gurush; the customs duty at İzmir was 46 gurush." 27 This caused change of the route of silk trade. In addition to internal conditions and difficulties, there were also certain external and especially political reasons for the change of silk route.

\footnotetext{
${ }^{24}$ According to İnalcik, in the Levan $\mathrm{t}$ trade both the English and Dutch merchants were active in Indian cotton instead of Indian silk. However, they were very active in the Persian silk trade (H. İnalcik (1951), “Osmanli İmparatorluğunun Kuruluş ve İnkişafi Devrinde Türkiye'nin İktisadi Vaziyeti Üzerinde Bir Tetkik Münasebetiyle,” in Bellleten XV, pp. 167-173; H. İnalcik (1993), "Osmanli Pamuklu Pazari, Hindis tan ve İngiltere" in Osmanli Imparatorluğu, Toplum ve Ekonomi Üzerinde Arşiv Çalişmalari/ İncelemeler, H. İnalcik (ed.), Istanbul, pp. 268272).

${ }^{25}$ K. N. Chaudhuri (1978), The Trading World of Asia and the English India Company, 1660-1760, Cambridge University Press, pp. 343353.

${ }_{26}^{26}$ B. Masters (1988), The Origins of Western Economic Dominance in the East: Mercantilism and the Islamic Economy in Aleppo, 16001780, New York, p. 19.

${ }^{27}$ Steensgaard, The Asian Trade Revolution of the Seventeenth Century, p. 34.
} 
Steensgaard believes that the conflict between the Ottomans and the Safavids caused a shift of the silk trading center from Aleppo to İzmir. ${ }^{28} \mathrm{He}$ writes: "It was in the years following the resumption of the Persian-Turkish war in the winter of 1622-23 that Smyrna (İzmir) became a serious competitor to Aleppo as the terminus for the Persian silk caravans. ${ }^{, 29}$ Frustrated European and Ottoman merchants rushed to İzmir as a more dependable and less expensive silk market. The reason seems to be that this new trade route was relatively safe and that the custom duties were comparatively low. The former route had many more customs stations. Thus, the change of the silk trade in general and therefore also the Dutch silk trade from Aleppo to İzmir may be explained with respect to transport costs and regional political conditions.

The East-West silk trade route always represented a political issue among Ottomans and Persians alike; the Persians tried to sever this route through persuading the Dutch and English merchants to change their trade routes from the Ottoman areas to Europe. The Persian Shah's capitulations to the English and the Dutch in 1623 created certain possibilities for an extension of the VOC's trade in silk. Shah Abbas planned to sell Iranian silk directly to Europe, diverting the silk route from Ottoman territory to the Indian Ocean. He found out that the Dutch and English, who by then established supremacy in the Indian Ocean, were keen to cooperate on eliminating the Ottomans as an intermediary because of the taxes that had to be paid in the Ottoman ports. According to Glamann, the Dutch secured "a share" in the mighty international silk trade carried out under the royal monopoly. Before 1623, exports were transported exclusively by way of Aleppo and Syria via the Levant and 3,000 bales were distributed to Marseilles, 1,500 to Venice, 400 to Italian towns (Genoa, Lucca, Florence, Messina, etc.), 600 to England, and 500 bales to the Dutch Republic. ${ }^{30}$ The Persian policy of changing the silk route clearly affected the Dutch silk trade in Ottoman territories.

Developments in the production of cotton textiles and trade in these goods are central to an understanding of the internal dynamics of the Ottoman economy and its connections with the western European economy. Cotton goods were the main consumption item for large population masses in the Ottoman Empire; thus, the domestic demand for those goods was extensive. Cotton was in demand not only in the Empire, but also in the East and West. Throughout the seventeenth century, textile products were traded between Asian, European and far Eastern merchants. Those merchants visited Ottoman trading centers, especially cities along the caravan trade routes. Goods from India brought Asian and western European merchants together. ${ }^{31}$ By expanding trade eastward to India, the Levant merchants assured themselves control over cheap sources of their goods. ${ }^{32}$ Indian cottons occupied an important place among Ottoman imports in the sixteenth and seventeenth centuries. ${ }^{33}$ Fine Indian muslins were among the luxury items used for men's and women's clothing. A price register from 1640 shows that expensive Indian muslin varieties dominated the Ottoman market while cheaper cotton goods were products of domestic manufacturing. ${ }^{34}$

The Genoese and Venetians had long dominated the Anatolian cotton export. ${ }^{35}$ During the first decades of the seventeenth century, the English and Dutch merchants broke their monopoly and participated even more actively in the cotton trade. By 1621, both English and Dutch merchant vessels from the Levant transported over 43,000 pounds of cotton per year to the port of London. ${ }^{36}$ The competition between Western nations in the cotton trade of İzmir increased considerably in the second quarter of the seventeenth century. ${ }^{37}$

After highlighting the key importance of İzmir as an international entrepôt for bulky commodities and textile goods, by referring to the explanations of Lewes Roberts, Goffman points out to the following: "Trade of this port is most noted for the abundance of cottons which hence is transported to England, France, Holland, and Italy, estimated yearly to be about 20,000 quintal, and is found here to grow in the

\footnotetext{
${ }^{28}$ Steensgaard, The Asian Trade Revolution of the Seventeenth Century, pp. 185-186.

${ }^{29}$ Steensgaard, The Asian Trade Revolution of the Seventeenth Century, pp. 34, 186.

${ }^{30}$ K. Glamann (1958), Dutch Asiatic Trade 1620-1740, The Hague, pp. 114-115.

${ }^{31}$ K. N. Chaudhuri (1965), The English East India Company: The Study of an Early Joint-stock Company, London, pp. 173-190.

32 B. Braude (1979), "International competition and domestic cloth in the Ottoman Empire, 1500-1650: A study in underdevelopment,"

Review, Vol. 2, no. 3, pp. 443.

${ }^{33}$ BBA Düveli Ecnebiye Defterleri (ED) 13/ 1: 3; 12.

${ }^{34}$ Y. Yücel (ed.) (1974), Kitab-i Mustetab, Ankara, pp. 41-59.

${ }^{35}$ E. Asthor (1976), "The Venetian Cotton Trade in Syria in the Latter Middle Ages," Studi Medievali Vol. 17, pp. 675-715.

39 A. M, Millard (1956), The Import of London, 1600-1640, PhD dissertation, University of London. BBA ED, 13/1, 30 .
} 
adjoining plains. ${ }^{38}$ Competition among the Atlantic nations led to wars towards the middle of the century, most notably the three Anglo-Dutch wars. The English won the first Anglo-Dutch war (16521654) in the North Sea, but it was won by the Dutch in the Mediterranean. The cause of the first war was the proclamation of the Navigation Acts, which constituted a direct attack on Dutch shipping in general. During the second Anglo-Dutch War (1665-1667), both sides were involved in warfare, and the French began to increase their share in the Mediterranean trade.

The struggle between the Ottomans and the Venetians created new possibilities for the Dutch, English and French merchants. Thus, Venetian trade in manufactured products declined in the Levant at the outbreak of the Ottoman-Venetian war in $1645 .{ }^{39}$ The position of their trade was weakened because of the high prices of the goods they exported and the excessive taxes levied on those exports. This further created a great opportunity for the northwestern European textile industry.

According to Davis the Dutch trade declined rapidly after $1660 .{ }^{40}$ For him the English achievement was dependent on the decline of the French, Venetian and Dutch export of cloth to the Levant. ${ }^{41}$ Davis also maintained that "England was ... for several decades in the middle of the seventeenth century ... much the largest western trader with Turkey." ${ }^{22}$ It is difficult to compare the value of Dutch and English imports and exports to and from the Empire in the middle of the century. However, at least in the third quarter of the century, the Dutch might have been stronger in the export of textile products to the Levant than other Western nations. Heeringa indicates that the chief Dutch convoy to İzmir brought four or five thousand lakens in 1660s. For the same period, the French historian Masson states that the Dutch laken export was about 6,000 or 7,000 pieces annually. ${ }^{43}$ Especially from the 1670 s onwards, competition became stronger ${ }^{44}$ among the English, French, Venetian and Dutch merchants. In his diary, Antoine Galland noted that English ships fought with 42 Dutch ships; the former captured the crew of five Dutch ships and defeated the others. According to the letter sent from Amsterdam on March 29, 1672, an English naval force with 15 ships attacked the Dutch convoy sailing from İzmir to the Netherlands. $^{45}$

In 1680, the Ottomans renewed the Dutch capitulations; ${ }^{46}$ and thus, the Ottomans continued to pursue friendly relations with the Dutch Republic. According to the first capitulations granted to the English in 1580 and the Dutch in 1612, the customs duty was 3\%, while it was set at 5\% for the French in 1569. Thus, the Dutch and English merchants were granted more privileges than their French counterparts during the first half of the century. This situation continued up until the year of 1673 during which, the Ottomans provided the French with a new capitulation and consequently the customs duty was reduced to 3\%. In the new English capitulations (1675), the customs duty was also 3\%. After the granting of new capitulations, the French Levant trade began to flourish as had the English and Dutch. Around 1680, according to Wood, there was a significant increase in the imports of Indian raw silk by Dutch merchants and a determined effort had been made in the previous ten years to develop the trade in manufactured silk goods in the Ottoman Empire. ${ }^{47}$ Cernovodeanu concluded that the English trade in the Levant declined in the last twenty years of the seventeenth century. ${ }^{48}$ Dutch profits rose faster,

\footnotetext{
${ }_{38}^{38}$ D. Goffman (1990), İzmir and Levantine World 1550-1650, University of Washington Press, p. 53.

${ }^{39}$ Setton states that the two wars the Venetians waged with the Ottomans (1645-1669 and 1684-1699) were costly and reduced the Venetians' commercial revenues to disastrously low levels. He concludes that during this period the English, French and the Dutch came into possession of a large part of the Eastern Mediterranean trade (K. M. Setton (1991), Venice, Austria, and the Turks in the Seventeenth Century, The American Philosophical Society Press, p. 364).

${ }^{40}$ R. Davis (1973), Rise of the Atlantic Economies, London.

${ }^{41}$ R. Davis (1973), Rise of the Atlantic Economies, London, pp. 36-45.

${ }^{42}$ R. Davis (1970), "English Imports from the Middle East, 1580-1780," in M.A. Cook (ed.), Studies in the Economic History of the Middle East from the Rise of Islam to the Present Day, Oxford University Press, pp. 193-206.

${ }^{43}$ P. Masson (1896), Histoire du commerce francais dans le Levant au XVIIe siècle, Paris, p. 126.

${ }^{44}$ These capturing activities were usual not only in the Ottoman ports, but also in the western part of the Mediterranean and even in the Atlantic. "A Dutch ship captured en route from Cadiz to Genoa in 1662 was carrying 140 bales of Castilian wool, 50,000 pieces-of-eight, and other costly goods, the whole cargo being valued at 195,000 guilders" (Israel 1989, 230). Because of the strong competition among the western nations and the wars, Dutch trading ships were escorted by their warships. There were three Anglo-Dutch wars in the second half of the century. The ships were equipped with canons and guns. For example, in 1662, two great ships and two warships docked in İzmir on 12 June and five great ships and two warships on 10 November (ARA LH 122). It means that the ships always had to be prepared for battle.

${ }^{45}$ C. Schefer (1949), Antoine Galland, İstanbul'a ait Günlük Hatiralar (1672-1673), N. S. Orik (trans.), Ankara, p. 136.

46 The new Dutch ambassador Colyer presented some gifts and money (6000 akçe and 30,000 ecu) to the Ottoman Sultan in Istanbul for renewal of the capitulations. For detailed information on this topic see R. Mantran (1990), XVI-XVII. Yüzyillarda Osmanli Imparatorluğu," M.A. Kiliçbay (trans.), Ankara; R. Mantran (1988) "XVII. Yüzyilin İkinci Yarisinda Doğu Akdenizde Ticaret, Deniz Korsanliği ve Gemiler Kafileleri," Belleten, pp. 690-707.

${ }^{47}$ A. C. Wood (1964), A History of the Levant Company, London, p. 105.

${ }^{48}$ P. Cernovodeanu (1972), England's Trade Policy in the Levant and her Exchange of Goods with the Romanian Countries under the Latter Stuarts (1660-1714), Bucharest, p. 34.
} 
however, because the high-quality Dutch cloth was a more highly finished and a costlier product than English woolen cloth. ${ }^{49}$

Likewise, France followed a strong mercantilist policy in the Levant and made some changes in its trade policies in the last quarter of the century. Before the mercantilist measures taken by the French Finance Minister, Colbert, the Dutch and English continued their important position as Western traders in the Empire. However, "after the measures advocated by Colbert, France's commercial policy involved the conversion of Marseilles into a 'free port' with greatly reduced taxes, encouragement of the French woolen industry, and the organization $(1670)$ and reorganization $(1678,1685)$ of a national company for trading in the Levant. Owing at least partly to these shifts in policy, and to France's recovery of prestige in the Ottoman capital, marked by the new capitulations of 1673, French trade figures once again began to rise, this time for a long period. France also had other advantages that began to work to her advantage. Less interested than the English or Dutch had been in the silk offered in the East, France was nevertheless far better able to absorb other raw materials such as cotton, grain, and hides which were obtained in the East." 50

On the one hand, the average annual amount of English cloth sold by the Levant Company in the Levant over the 1688-1697 period came to around 12,329 bales, some of which was captured by French vessels or lost at sea and did not reach their place of destination. ${ }^{51}$ On the other hand, the annual average regarding French exports to Levant, which arrived at their destination, was from 2.5 to 3 million livres between the years 1670 and 1680 . This amount rose over the $1684-1687$ and $1688-1694$ periods to 5.6 million and 7.7 million livres, respectively. The average in the 1698-1700 period rose to nearly 11 million livres. ${ }^{52}$ Colbert maintained that the Dutch profitable trade in the several trade areas increased in the seventeenth century. ${ }^{53}$ Colbert's assessment, although grossly overestimating the Dutch rich trade, indicates that the Levant trade became very important for Dutch foreign trade and economy during their Golden Age. ${ }^{54}$ The evidence indicates that Colbert's strong mercantilist policy against the Dutch succeeded towards the close of the seventeenth century.

\section{Change and Transformation in the Relations between the Ottomans and Atlantic Nations}

According to the archival registers ${ }^{55}$ Dutch trade and shipping encountered strong mercantilist competition from both the English and the French towards the end of the seventeenth century. The reports of Jacob Turner, an English merchant in the Levant, also indicate that competition among the Western traders in textile raw materials, such as silk, cotton, mohair and wool, increased considerably in the Levant during the last decades of the century, especially between French, English and Dutch merchants. ${ }^{56}$ The other main purpose of the Western traders was to control the export of manufactured products to the Empire. However, not only were they concerned with trade between the Levant and the West, but they also had dealings with various commission houses in both areas. Their commodities were not limited to these four products of the Ottomans, but also included currants, hides, wood, wax, pepper, tin, copper and lead.

France began to follow a strong mercantilist strategy in the Levant against the Dutch and English traders as well as the North African corsairs. Especially in the last quarter of the seventeenth and early decades of the eighteenth centuries, this French trading strategy became tougher in the region. "The war against

\footnotetext{
${ }^{49}$ In Ottoman terminology, Dutch and English cloth was used as cuka: “...Istanbul ve Galata iskelelerine getürdükleri Londra ve Ingiltere'de işlenen cukalar gerek a'lâ ve gerek edna her ne bahada olursa olsun kanun-u kadim ve viregeldikleri üzre her pastavindan riyal gurus seksener ve esedi gurus yetmis akçeye olmak üzere yüz kirk dört akçe alinub ziyade alinmaya. Amma Felemenk ve sayir vilayetlerin cukalarin ki sa'ya ve londrin ve iskarlat ve sair cukalardir kadimden ne minval üzre gümrük alinagelmiş ise olminval üzre vireler ve Izmir'de kadimden viregeldikleri üzre yine riyal ve esedi sağ hesabinca gerek a'lâ ve gerek edna her pastav londra ve sair cukalar..." (The customs duties for a roll of cloth (cuka), which was manufactured in London and in England, brought to the Galata and Istanbul ports were without any respect to their qualities and their prices, were 144 akçe (Dutch Leeuwendaalders 70 akçe; Spanish rial 80 akçe each) (A. Refik (1988), Onikinci Asr-i Hicride Istanbul Hayati 1590-1785, Istanbul, p. 42).

${ }^{50}$ R. Davis (1967), Aleppo and Devonshire Square: English Traders in the Levant in the Eighteenth Century, London, pp. $28-29$.

${ }^{51}$ P. Cernovodeanu. England's Trade Policy in the Levant, p. 37.

53 Masson, Histoire du commerce francais dans le Levant, pp. 286; 294-295; 556.

${ }^{54}$ There is a common view that the Levant trade had a minor role in Dutch foreign trade and economy in the seventeenth century and that the Dutch East India trade (VOC) was the most important area for the Dutch foreign trade and economy in the world. However, the estimation of Attman also supports Colbert's conclusion. According to Attman, in the 1680s, the Dutch Levant was equal in volume to the VOC and WIC trade (A. Attman, Dutch Enterprise in the World Bullion Trade, p. 40).

${ }^{55}$ The Ottoman registers of (BBA ED 22; MM 6004: 1, 3, 4, 54) contain a great deal of information on this topic. (ARA LH 97-102, 121-125, $161,168,172)$ include more details on the competition between Western nations in the Levant in the second half of the century.

56 J. A. Elin (1976), A Seventeenth Century Levant Merchant: The Life and Letters of Jacob Turner, PhD Thesis, New York University, pp. 51-62.
} 
the North African pirates was continued and from 1687 to 1699 was financed by a tax of 3 livres a ton on ships plying between France and the Levant. Up to 1692 the seas were somewhat safer for French ships, but in that year the corsairs of Tripoli, encouraged by the Dutch and the English, declared war on France. Tripoli was bombarded without much effect by the French in August of 1692, and French influence at Istanbul forced the pirates to make peace the next year. In the remaining years of the war, other pirates, supplemented by Dutch and English privateers." ${ }^{, 57}$

Fresh mercantilist policy aimed to make Marseilles an entrepôt for the Levant trade. At the beginning of the eighteenth century, Turkish commodities began to flow into the Dutch entrepôt (often on Dutch ships) from France. This meant that Holland was losing control of the traffic in a key group of commodities. Dutch merchants, backed by the Directorate of the Levant trade and the Amsterdam city council, urged immediate action in the shape of States General ban on the import of Ottoman commodities into the United Provinces from any country other than the Empire. However, there was strong opposition from the textile towns. This period can be considered the beginning of a new phase of the French role in the Ottoman textile market during which French merchants began to play a more significant role in the East Mediterranean. ${ }^{58}$ The French had successfully exported manufactured Dutchstyle woolen cloths to the Ottomans.

The rise of France is one of the causes of the decline of Dutch trade and shipping to the Levant in the final decades of the seventeenth century. In 1701, the Dutch consul at İzmir reported that the sale of Leiden lakens in the Ottoman Empire was now down to 2,500 annually, less than half the level before 1672. The French began to sell more cloth in the markets of the Empire than the Dutch did. ${ }^{59}$ French merchants were also purchasing more mohair yarn as well as Persian raw silk, gallnuts, and coffee than Dutch traders towards the end of the seventeenth century. The Ottoman Empire had also chosen England as an ally in the West like France and the Dutch Republic. The Ottomans also gave them new capitulations. In particular, English cloth exports began to increase after the Ottoman-Venetian war and the collapse of the Venetian cloth industry. During the 1670s, the average annual English exports increased significantly, but specific yearly shipments fluctuated widely. The most significant cause of these variances of exports was the Anglo-Dutch war which made commercial shipping dangerous. ${ }^{60}$ Cernovodeanu showed that the English trade in the Ottoman territories declined in the last 20 years of the seventeenth century and concludes that this was due to keen French competition and also to the sharp rivalry ${ }^{61}$ between the English Levant Company and the Dutch East India Company. ${ }^{62}$

From the first decades of the eighteenth century, the economic relations between the Ottoman Empire and France were developing due to the new conditions of the world economy and politics. Political relations also improved with the Porte and the French, especially because of the hostility of Louis XIV to the Hapsburg Empire. The Ottomans also granted a new capitulation to France and the 5\% customs duty levied by the Ottoman authorities on the value of goods was lowered in the new capitulations concluded in 1673 to the same 3\% paid by the English ${ }^{63}$ and Dutch merchants.

From the beginning of the eighteenth century, however, sales of cloth from France began to accelerate in the Ottoman Empire. Reports reached France from the trading centers of the Empire such as Istanbul and İzmir indicate that fine French cloth was now "seriously undermining sales of Dutch lakens in the Ottoman area." ${ }^{64}$ According to Wood, the English Levant trade also declined at the same period. English textile exports to the Empire declined by nearly 5000 bales of cloth per year. ${ }^{65}$ This decline was attributed partly to the renewed status of the French textile industry in the Levant and also in part to the effect of the Dutch competition. For the same period, Masson estimates that the Dutch purchases of Turkish mohair were as high as 300,000 lb. or 1,900 bales amounting to 6 million livres annually. ${ }^{66}$

\footnotetext{
${ }^{57}$ C. W. Cole (1943), French Mercantilism, 1683-1700, Colombia University Press, New York, pp. 26-27.

${ }^{58}$ R. Mantran, XVI-XVII. Yüzyillarda Osmanli Imparatorluğu, p. 165.

${ }^{59}$ In 1698, e.g., the French were selling 3,200 rolls of cloth to Turkey (Israel, Dutch Primacy in World Trade, p. 311).

${ }_{61}^{60}$ A. C. Wood, A History of the Levant Company, p. 102.

${ }^{61}$ For more information on this competition and wars see, G. J. A. Raven \& N. A. M. Rodger (eds.) (1990), Navies and Armies, The AngloDutch Relationship in War and Peace 1688-1988, Edinburgh.

${ }^{62}$ Cernovodeanu, England's Trade Policy in the Levant, pp. 34-35.

${ }^{63}$ According to the English capitulation of 1675, English merchants also had to pay the 3\% customs duty.

${ }^{64}$ J. Israel, Dutch Primacy in World Trade, p. 309.

${ }^{65}$ A. C. Wood, A History of the Levant Company, p. 102.

${ }^{66}$ P. Masson, Histoire du commerce francais dans le Levant, p. 374.
} 
However, Heerenga estimates that the Dutch purchases were higher than Masson's estimation of that same period. ${ }^{67}$

Table 2. Shares of the major European nations in the Levant trade, 1686-1784 (in livres tournois and percentages)

\begin{tabular}{|l||l|l||l|l|l|l||l|l||l|}
\hline Year & Dutch & $\%$ & France & $\%$ & England & $\%$ & Venice & $\%$ & Austria\% \\
\hline 1686 & $3,697,440$ & 38.3 & $1,519,290$ & 15.7 & $4,184,700$ & 43.4 & 246,900 & 2.6 & \\
\hline 1750 & 134,164 & 3.4 & $2,550,868$ & 65.1 & 595,850 & 15.2 & 637,421 & 16.3 & \\
\hline 1776 & $4,300,901$ & 14.4 & $13,448,791$ & 45.1 & $7,432,045$ & 24.9 & $2,875,279$ & 9.6 & 2.9 \\
\hline 1784 & & 18.3 & & 36.5 & & 9.2 & & 12.0 & 24.0 \\
\hline
\end{tabular}

Source: B. McGowan (1981), Economic Life in Ottoman Europe: Taxation, Trade and the Struggle for Land, 1600-1800, Cambridge University Press.

"The letters from Smyrna (Izmir) suggested another reason for the dull market: Dutch competition. The Dutch were also forced by the renewed French cloth trade to dispose of their cloth very cheaply. In June 1685 , they imported a large supply of londrine, a quality of cloth developed in the seventeenth century specifically to compete with English londra ${ }^{68}$. The Dutch sold the cloth 'giving half money with there londrinaes' and also ran 'furriously on all sorts Comoditys...' While the londrine's low price seriously affected English cloth sales, the Dutch demand for goods caused a general price increase on the Smyrna market." 99

Compared to the French exports in the 1698-1700 period, the English exports were less; while the value of the French exports amounted to 11 million livres that of the English reached only $£ 173,055$ or 2,076,660 livres..$^{70}$ At the end of the seventeenth century, in the Levant, the Dutch lakens had fallen by over half from the levels prevailing before 1689, and sold at only about 2,500 annually. ${ }^{71}$ Thus practically, the French took control of half of the former Dutch cloth market in the Levant during this period. French consuls also supported their merchant community against the Dutch in the Levant. The Dutch merchants suffered from the French community in Aleppo and İzmir. ${ }^{72}$ The letters of the merchants and the reports of the Dutch consuls in İzmir indicate that the complaints of the Dutch merchants increased in the last decades of the century due to the activities of the French consul and community in the Levant. ${ }^{73}$ At the end of the century, however, the Dutch still were shipping and trading in the Levant. According to Heeringa, 180 Dutch ships returned to the Netherlands from Levant ports annually. ${ }^{74}$

In the last decades of the seventeenth century, Ottoman-Atlantic economic relations continued to develop in the East Mediterranean. However, the Dutch Levant trade declined. The main reason for the Dutch decline was the strong mercantilist French and English policies against them, but the policies of the Sublime Porte did not change. The Dutch merchants still played a role in the trade between the Ottoman Empire and the French by trading goods from the ports of the Levant to the Atlantic ports of France. ${ }^{75}$ In the Levant, there was very strong competition, even rivalry, among these Western commercial powers in the seventeenth and eighteenth centuries. In the seventeenth century, this competition evolved into wars between the Dutch Republic and England. The competition continued into the following century. Perhaps the rivalry between England and France is the most conspicuous feature of eighteenth-century history from 1700 to $1763 .^{76}$ Davis asserted that France was the only

\footnotetext{
${ }^{67}$ K. Heeringa, Bronnen tot de Geschiedenis van den Levantschen Handel, pp. 102-103.

${ }^{68}$ Londrin in Ottoman terminology.

${ }^{69}$ J. A. Elin, A Seventeenth Century Levant Merchant, pp. 111-112.

${ }^{70} £ 1=12$ livres.

${ }^{71}$ K. Heeringa, Bronnen tot de Geschiedenis van den Levantschen Handel, pp. 99-103.

${ }^{72}$ The competition between the Dutch and French increased in Aleppo in the last decades of the century. Occasionally this competition led to battle at sea. On April 28, 1693 French merchants attacked Dutch merchants using guns and other weapons. Such conflicts increased in İzmir as wel 1. The Dutch consul Hochipie had to go to Istanbul to discuss the problems with the Dutch and French ambassadors and tried to solve the problems. For more information on such conflicts among the two communities, see ARA LH pp. 125-127

${ }^{73}$ ARA LH pp. $125 \& 127$.

${ }^{74}$ K. Heeringa, Bronnen tot de Geschiedenis van den Levantschen Handel, p. 112. However, De Vries and Van der Woude calculated an average of 123 ships per year from 1697-1700 (J. De Vries, J. \& A. Van der Woude (1997), The First Modern Economy: Success, Failure, and Perseverance of the Dutch Economy, 1500- 1815, Cambridge University Press, p. 381).

${ }_{75}$ C. W. Cole, French Mercantilism, p. 27.

${ }^{76}$ For more information on the rivalry between France and England, see C. M. Andrews (1915), "Anglo-French Commercial Rivalry 17001750: The Western Phase" The American Historical Review, Vol. 20, no. 3, pp. 539-556
} 
country whose seaborne trade with the Levant rivalled England's in the seventeenth and most of the eighteenth century. ${ }^{77}$ The English trade essentially consisted of exchange of cloth for raw silks, similar to the exchange of lakens for mohair yarn where the Dutch were more important than the English and the French together. Cernovodeanu wrote:

The Dutch and English, therefore, found the trade of the Mediterranean divided between them and something like a division of labor set in. The Dutch sold the fine cloth, linens, camlets, and most of the spices; the English sold the lower-grade cloth. Both nations bought raw silks in Turkey and Italy. On balance, the English seem to have continued to purchase more raw silk in Italy and the Levant than the Dutch; the shipping of raw silk from the Mediterranean remained a marginal activity for the Dutch entrepôt, designed to supplement the supplies shipped direct from Persia and India by the VOC and via Russia and the Dutch Muscovy convoys. ${ }^{78}$

Concerning the trade in woolen cloth, England clearly held a stronger position than the Dutch. In the Levant silk trade, English merchants were also more active than the Dutch. Evidence reveals that the amount of silk imported by the Dutch from Ottoman territories was lower than the amount imported by the English. ${ }^{79}$

In the Levant, due to various trading advantages and the system of capitulations, there was a kind of balance among these Western trading nations at the beginning of the century. However, after the second decade of the eighteenth century, France gradually began to replace both the Dutch and English merchants in the Ottoman territories, reaching a share of more than $60 \%$ of this trade by the middle of the century. ${ }^{80}$ This position did not change significantly until the end of the eighteenth century when the French Revolution and its consequences would wipe out French commercial interests from the Levant. In addition to French mercantilist policies, the Dutch decline and the diversification of English commercial interests towards the Indian and Atlantic Oceans played a role in the increasing French share in the Levant trade in the eighteenth century. ${ }^{81}$

The French political and diplomatic networks within the Ottoman bureaucracy and ruling elite also played a role in their commercial expansion in the Levant. Renewal of French capitulations in 1740 is yet another indication of their good contacts with the Ottoman ruling class. The new capitulations meant that they reached the most privileged position compared with other European competitors and were most favored nation in Ottoman international trade by the middle of the eighteenth century. Beginning with the 1760s, Ottoman exports to France from the western port, Izmir, grew faster than the trade of the Ottoman Empire as a whole. ${ }^{82}$ This Ottoman city, Izmir, also dominated the Ottoman Empire's importation of French goods. And while Izmir was the most important Levantine city port for commercial relations with France in the eighteenth century, Marseilles was similarly important in France for relations with the Ottoman Empire. Izmir's share of the total value of the empire's cotton exports to Marseilles was only around $10 \%$ between 1700 and 1720 , but it reached $44 \%$ in $1750-1754$. In $1785-1789$, it reached $70 \%$, which marked the peak years of the French trade. ${ }^{83}$

According to Hanway, English raw cotton imports from the Ottoman Empire between 1721 and 1740 was about 330,000 great pounds (24 ounces) per year. ${ }^{84}$ Freight contracts reveal that Dutch ships and cargoes from the Mediterranean, loaded at Cyprus, Syrian and western Anatolian ports, predominantly transported cotton yarn. ${ }^{85}$ The moderate volume of cotton exports seems to have been evenly distributed among Syrian and Anatolian ports. During the seventeenth century, cotton was of the same importance to the Dutch and English, who mostly obtained their raw cotton from Cyprus and İzmir. However, this item was more important for the English, whose spinning industry in Lancashire was built upon

\footnotetext{
${ }^{77}$ R. Davis, English Imports from the Middle East, p. 203.

${ }^{78}$ J. Israel, Dutch Primacy in World Trade, pp. 226-227.

${ }^{79}$ P. Cernovodeanu, England's Trade Policy in the Levant; M. Çizakça (1985), "Incorporation of the Middle East into the European WorldEconomy," Review, Vol. 8, pp. 353-377.

${ }^{80}$ E. Eldem (1999), "French Trade and Commercial Policy in the Levant in the Eighteenth Century," Oriento Moderno, Vol. 1, p. 27.

${ }^{81}$ Cernovodeanu (1967), "The General Condition of English Trade in the Levant in the second half of the $17^{\text {th }}$ century and at the beginning of the $18^{\text {th }}$ century," Revue des Etudes Sud-Est Européennes, Vol. 5; R. Davis, English Imports from the Middle East.

${ }^{82}$ E. Frangakis-Syrett (1999), "The Economic Activities of Ottoman and Western Communities in Eighteenth Century Izmir," Oriento Moderno, Vol. 1, p. 11.

${ }^{83}$ E. Frangakis-Syrett, “The Economic Activities of Ottoman and Western Communities,” p. 12.

${ }^{84}$ J. Hanway, An Historical Account of the British Trade, p. 54

${ }^{85}$ AGA NA 89/ 225 (1601), NA 98/151 (1604), NA 102/103 (1605), NA 112/185 (1608), NA 116/174 (1609).
} 
Levantine cotton, than for the Dutch. Both English and Dutch merchants sometimes purchased cotton from the Cyprus Ottoman merchants on credit. ${ }^{86}$ It is known that in granting the English and Dutch capitulations, one of the Ottoman purposes was to secure war materials from the English and Dutch merchants. Powder, iron, copper, tin, lead and saltpeter were important inputs for the Ottoman Empire at that time. ${ }^{87}$ Some raw materials, such as iron, were clearly brought to the Ottoman Empire in large quantities through Holland and Leghorn during the seventeenth and eighteenth centuries ${ }^{88}$ Moreover, English, French and Dutch merchants regularly exported firearms to the Ottoman Empire. ${ }^{89}$ Copper was another big business requiring large capital resources and good political connections during the early modern period because the Swedish crown closely regulated the country's copper exports. These items were also exported to the Ottoman Empire by Dutch and English merchants. ${ }^{90}$

The English and Dutch merchants purchased gunpowder and saltpeter from local sellers and brought them to Surat. ${ }^{91}$ They frequently faced serious problems, which were usually solved by bribing of local authorities. Sometimes local authorities prohibited the Dutch and English merchants from purchasing gunpowder and saltpeter because they believed that the merchants would sell them to the enemies of the Ottomans. ${ }^{92}$ Braudel believes that the English and the Dutch created a lucrative trade with the Ottomans in war materials. ${ }^{93}$ According to Parry, documents from the archives at Marseilles provide information about the transport of raw materials such as copper, steel and tin to the Levant. These registers noted that one of the cargoes the Dutch unloaded at İzmir contained 30,000 bombs. ${ }^{94}$

According to the Directors of English Levant Company, in 1774, during the preceding 20 years, the British cloth export to the Levant was $£ 180,000$ annually, exclusive of many other collateral articles of value. ${ }^{95}$ The average English export figures between 1784 and 1786 amounted to £13.6 million, while in 1794-96 and 1804-06 they were $£ 24$ million and $£ 41.2$ million respectively. According to the report of the French Consul Che' nier, in 1789, the number of ships used by the Venetians in the trade with the Ottoman Empire ranged between 15 and 18 with tonnages varying from 300 to 600 . At that time, the Dutch ships sent to the Ottoman Empire varied from 12 to 15 annually with tonnages between 400 and 600. The English were more active in the trade with the Ottoman Empire, with 17-20 ships sent each year of tonnages varying from 300 to 600 . As for the French, they were superior to all other European nations in their trade with the Ottoman Empire, with nearly 200 ships of tonnages varying from 150 to $350 .^{96}$

From the middle of the eighteenth century, western European nations began fundamental changes. The commercial rise of the Atlantic nations coincided with the introduction of machinery in production, world trade routes began to be used more frequently, transformation was improved, protective custom policies were adopted and the flow of raw materials from the rest of the world increased. The Ottomans played an important role in this respect. While Atlantic nations, especially France and England, followed strong mercantilist strategies in the Levant and the rest of the world, the Ottomans continued to follow their traditional foreign trade policies, which were based on encouraging importation and discouraging exportation until the middle of the nineteenth century. The Ottomans simultaneously faced long and costly wars in the west and its expenditures continued to increase, which led to an inflow of manufactured goods from the Atlantic to the Ottoman Empire and export of raw materials from the Empire to Western Europe. In summary, the Ottoman Empire increasingly opened its economy to the Atlantic nations in the eighteenth and nineteenth centuries. With the widening of the network between the two regions, the commercial relations of the Ottoman-Atlantic merchants increased significantly. This development created a new situation between the markets of the two regions: the Levant and Atlantic and Ottoman-Atlantic economic relations began to develop towards the integration of the European economy with the Levant.

\footnotetext{
${ }_{87}^{86}$ Davis, Aleppo and Devonshire Square, p. 27; A. C. Wood, A History of the Levant Company, p. 74.

${ }^{87}$ BBA MM 6006, p. 32.

${ }^{88}$ V. J. Parry (1970), "Materials of war in the Ottoman Empire," in M. A. Cook (ed.), Studies in the Economic History of the Middle East, From the Rise of Islam to the Present Day, Oxford University Press, p. 224.

${ }^{89}$ Observations on the Commerce of Great Britain with the Russian and Ottoman Empires and on the projects of Russia against the Ottoman and British Dominions, London, 1801, p. 13

${ }_{90}$ BBA MM 6006, p. 32.

${ }^{91}$ It seems that the Dutch and English merchants bought the war materials more cheaply than the Ottoman and Asian merchants.

${ }_{92} \mathrm{H}$. Furber (1976), Rival Empires of Trade in the Orient, 1600-1800, University of Minnesota Press, pp. 225,256

$92 \mathrm{H}$. Furber (1976), Rival Empires of Trade in the Orient, 1600-1800, U
${ }_{93}$ F. Braudel, The Mediterranean and the Mediterranean World, p. 479.

${ }^{94}$ V. J. Parry, Materials of War in the Ottoman Empire, pp. 219-229.

${ }^{95}$ Observations on the Commerce of Great Britain, pp. 10-11.

${ }^{96}$ M. Küçükkalay \& N. Elibol. Ottoman Imports in the Eighteenth Century: Smyrna (1771-72), pp. 732-733.
} 


\section{Conclusion}

During the early modern period, while the Ottoman and some European nations were hostile to each other at times, the relations between the Ottomans and the Atlantic nations, France, England and the Dutch usually appeared to be good and developed, especially in trade. Merchants from Western Europe and the Ottoman Empire were the main travelers of the Mediterranean and Atlantic waters. The establishment of friendly relations between the Ottoman Empire and Western European countries led to the growth of trade between the territories of the Empire and France, England and the Dutch Republic in early modern times. In the early sixteenth century, most Ottoman trade was conducted with the Italian states. However, France started to become the leading trade partner by the middle of the century. After France, English and Dutch merchants appeared in the Ottoman territories. The Dutch domination in the European and Asian trade extended to the Levant in the seventeenth century. In the seventeenth and eighteenth centuries, competition increased between the western European trading nations in the Ottoman territories. While England captured a big share from the Dutch in the seventeenth century, the French did the same in the eighteenth century. Until the massive flow of European capital into the Ottoman Empire began in the second half of the nineteenth century, the trade in goods was the sole economic link between the Empire and Atlantic nations.

The major routes between Europe and Asia by land and sea converged in the Near East and Asia Minor. In the East, the Ottomans extended their efforts to establish full control of the traditional silk route between East and West and that trade flourished. The Eastern Mediterranean region (the Levant) was also under Ottoman control. With its hinterland of economically integrated countries, the Levant was the world's most lively region for the exchange of goods and ideas between East and West before the great European trade route discoveries. Due to their position in the international economy and trade, and because the Ottomans controlled the trade routes, both maritime and land, between East and West. They continued to gain much revenue from transit trade. Spices and other valuable products from Asia and the Levant had found their way to Europe through the Ottoman territories for centuries. It can be said that after the collapse of the Roman Empire, the Ottomans were the first to integrate different regions and countries from the Gulf to the Balkans into a common economic space through a free flow of goods, capital and people, which resulted in reduced transactions costs. Although the primary trading products in the commerce between the Atlantic and Ottoman Empire were textile materials, merchants were not limited to textile products and Asian and colonial products. In the commerce among the merchants of the two regions, cattle, grain, grapes, and commodities such as figs, oil, sugar, cloves, wine, nutmeg, cinnamon, lead, tin, copper, mercury, wax and wood were also important.

The commercial expansion of Europe and the accumulation of capital led to the creation of new industries, particularly in the area of textiles, which had to find export markets to continue their expansion. The fundamental inputs of the French, English and Dutch textile industries were silk, cotton, linen, mohair yarn and wool. England mainly imported raw silk, wool and cotton while France and the Dutch Republic mainly imported cotton, raw silk and mohair yarn. The Levant trade was very profitable for merchants. The English and French Levant companies accumulated great wealth from this trade. Their consuls and ambassadors were active in protecting their commercial rights. Many of them were also personally involved in commercial activities. The Ottoman Empire's share in international trade did not decrease after the conquering European nations introduced alternative sea routes to these trades. The commercial relations between the Ottomans and European nations continued to increase until the middle of the nineteenth century. In addition to the continuation of western mercantilism, state interference, the birth of liberalism and the flexible, neutral, pragmatic and alternative Ottoman economic policies and models also played a role in the process and influenced those results.

Because of the different objectives and priorities set for the citizens of the Empire, the Ottomans adopted an "open door" policy towards the western mercantilist nations which alongside the Ottoman support, led the French, British and Dutch merchants and companies to accumulate great wealth in the early modern times. The commercial expansion of Northwestern European nations and the accumulation of capital also led to the creation of new industries in the West. Hence, traditional trading relations began to change between the Ottomans and the West during the industrialization era as shown in the exchange of the Ottoman raw materials began for the manufactured European goods. In addition to the several changes affecting the commercial relations between the two-world political, economic and financial relations were also affected in the following periods in addition to the very the nature of the relations 
between the Ottomans and European nations which got changed during the times of the industrial capitalism. The power based on wealth acquisition, capital accumulation and industrialization began to play crucial role in the shaping of relations whose manifested results can be grasped with regards to their different worldviews, value systems, mindsets and paradigms of those two worlds.

Prospect research should explore those worldviews and value systems further. This is specially needed given the currently profound differences in the values and paradigm of modern industrialized west with those of the Ottoman holistic approach and of many others communities throughout human history. One also needs to realize that the new capitalist materialistic paradigm introduced by modern industrialized West created serious spiritual, moral, ethical, environmental, socio-economic, and political dilemmas. Such a case requires re-thinking of modernization and industrialization worldview, values, systems, and processes and to focus on the alternative economic and trade perspective and model based on the Ottoman original archival resources and classical humanistic traditions.

\section{References}

Archival Resources

Ankara, Milli Kütüphane, Ankara Kadı Sicilleri (AKS), vols.: 3, 4, 5, 6, 7, 8, 65, 66, 67, 68, 69, 70, 71.

Istanbul, Başbakanlık Arşivi (BBA)

Bab-ı Asafi Kalemleri (BA), numbers: 30 and 902.

Cevdet Tasnifi (CT), Hariciye: 861

Bab-ı Harameyn Mukatası (BHM), number: 20

Ecnebiye Defterleri (ED), numbers: 13, 20, 22, 24, 26

Maliyeden Müdevver Defterler (MM), numbers: 2765, 6004, 6006, 6632 Muahedat Mecmuası

Mühimme Defterleri (MD), numbers: 73, 80, 90, 107

Mühimme Zeyli Defterleri (MZD), number: 8

Milli Tetebbular Mecmuası

Amsterdam, Gemeentelijke Archief (AGA)

Burg. Levantse Handel, I, II, V

Notarieel Archief (NA), numbers: 2, 87, 89, 95, 120, 121, 144, 150, 151, 187, 200, 201, 225, 226, 375 , $381,633,759,878,899,941,951,1088,1112,1500,2219,2755,3658,3688,3794,5494,5529,5884$

The Hague, Algemeen Rijksarchief (ARA)

Staten General, numbers: 12593/ 34, 35, 38, 57, 61, 63, 64, 72, 76.

Directie van de Levantse Handel (LH), numbers:

73, 74, 97, 98, 99, 100, 101, 102, 121, 122, 123, 124, 125, 126, 127, 128, 161, 5028.

Lias Barbarije, numbers: 6889, 6898, 6900, 6901.

Secondary Resources

Abbott, G. F. (1920), Under the Turk in Constantinople: A Record of Sir John Firch's Embassy 16741681, London.

Ali Re'is, S. (1999), Mir'âtü'l-Memâlik: Inceleme, Metin, Indeks, M. Kiremit (ed.), Ankara: Turk Dil Kurumu Press.

Andrews, C. M. (1915), “Anglo-French Commercial Rivalry 1700-1750: The Western Phase," The American Historical Review, Vol. 20, no. 3, 539-556.

Asthor, E. (1976), "The Venetian Cotton Trade in Syria in the Latter Middle Ages," Studi Medievali, Vol. 17.

Attman, A. (1983), Dutch Enterprise in the World Bullion Trade, 1550-1800, Goteborg. 
Journal of Al-Tamaddun, Vol. 15 (1), 2020, 13-30

Barkan, Ö. L. (1958), "Essai sur les Donnees statistiques des registres de recensement dans l'empire Ottoman au XVe et XVIe siecles," Journal of the Economic and Social History of the Orient, Vol. 1, no. 1, 9-36.

Beawes, W. (1792), Lex Mercatoria Rediviva: Or, A Complete Code of Commercial law. Being a general guide to all men business,.. with an account of our., London.

Braude, B. (1979), "International Competition and Domestic cloth in the Ottoman Empire, 1500-1650: A study in undevelopment," Review, Vol. 2, no. 3.

Braudel, F. (1972), The Mediterranean and the Mediterranean World in the Age of Philip II, S. Reynolds (ed.), New York.

Bulut, M. (2001), Ottoman-Dutch Economic Relations in the early modern period, 1571-1699, Verloren.

Casale, C. (2010), The Ottoman Age of Exploration, New York: Oxford University Press.

Cernovodeanu, P. (1972), England's Trade Policy in the Levant and her Exchange of Goods with the Romanian Countries under the Latter Stuarts (1660-1714), Bucharest.

Cernovodeanu, P. (1967), "The General Condition of English Trade in the Levant in the second half of the $17^{\text {th }}$ century and at the beginning of the $18^{\text {th }}$ century," Revue des Etudes Sud-Est Européennes, Vol. 5.

Chaudhuri, K. N. (1978), The Trading World of Asia and the English India Company, 1660-1760, Cambridge University Press.

Chaudhuri, K. N. (1965), The English East India Company: The Study of an Early Joint-stock Company, London.

Cole, C. W. (1943), French Mercantilism: 1683-1700, New York: Colombia University Press.

Çizakça, M. (1985), "Incorporation of the Middle East into the European World-Economy," Review, Vol. 8, 353-377.

Davis, R. (1973), Rise of the Atlantic Economies, London.

Davis, R. (1970), "English Imports from the Middle East, 1580-1780," in M.A. Cook (ed.), Studies in the Economic History of the Middle East from the Rise of Islam to the Present Day, 193-206, Oxford University Press.

Davis, R. (1967), Aleppo and Devonshire Square: English Traders in the Levant in the Eighteenth Century, London.

De Vries, J. \& Van der Woude, A. (1997), The First Modern Economy: Success, Failure, and Perseverance of the Dutch Economy, 1500-1815, Cambridge University Press.

Eldem, E. (1999), French Trade in Istanbul in the Eighteenth Century, Leidin: Brill.

Elin, J. A. (1976), A Seventeenth Century Levant Merchant: The Life and Letters of Jacob Turner, PhD Thesis, New York University.

Erdbrink, G. R. B. (1975), At the Threshold of Felicity: Ottoman-Dutch Relations During the Sublime Embassy of Cornelis Calkoen at the Sublime Porte, 1726-1744, Ankara.

Ferguson, N. (2004), Empire: How Britain Made the Modern World, London. 
The Ottomans and Western Europeans during the Mercantilist Times

Frangakis-Syrett, E. (1999), "The Economic Activities of Ottoman and Western Communities in Eighteenth Century Izmir," Oriento Moderno, Vol. 1, 11-26.

Furber, H. (1976), Rival Empires of Trade in the Orient, 1600-1800, University of Minnesota Press.

Glamann, K. (1958), Dutch Asiatic Trade 1620-1740, The Hague.

Goldstone, J. A. (1990), Revolution and Rebellion in the Early Modern World, University of California Press.

Goffman, D. (1990), Izmir and Levantine World 1550-1650, University of Washington Press.

Griffits, P. (1974), The History of English Chartered Companies, London.

Hakluyt, R. (1927), The Principal Navigations, Voyages, Traffiques and Discoveries of the English Nation, London.

Hanway, J. (1754), An Historical Account of the British Trade over the Caspian Sea, London.

Heeringa, K. (ed.) (1910), Bronnen tot de Geschiedenis van den Levantschen Handel, (1590-1726), RGP: 9,10,34, The Hague.

Hobson, J. M. (2004), The Eastern Origin of Western Civilisation, Cambridge.

Israel, J. (1989), Dutch Primacy in World Trade, 1585-1740, Oxford.

İnalcik, H., \& Quataert, D. (eds.) (1997), An Economic and Social History of the Ottoman Empire: The Ottoman Empire 1300-1914, 2 vols, Cambridge University Press.

İnalcik, H., \& Quataert, D. (1951), "Osmanli İmparatorluğunun Kuruluş ve İnkişafi Devrinde Türkiye'nin İktisadi Vaziyeti Üzerinde Bir Tetkik Münasebetiyle,” in Bellleten XV, 167-173.

İnalcik, H., \& Quataert, D. (1993), "Osmanli Pamuklu Pazari, Hindistan ve İngiltere," in H. İnalcik (ed.), Osmanli İmparatorluğu, Toplum ve Ekonomi Üzerinde Arşiv Çalişmalari/ İncelemeler, 268-272.

Jennings, R. (1993), Christians and Muslims in Ottoman Cyprus and the Mediterranean World, 15711640, New York University Press.

Kurat, A. N. (1953), Türk-İngiliz Münasebetlerinin Başlangici ve Gelişmesi, Ankara.

Küçükkalay, M., \& Elibol, N. (2006), "Ottoman Imports in the Eighteenth Century: Smyrna (177172)," Middle Eastern Studies, Vol. 42, no 5, 723-740.

Leiden, Leiden University Library, Oriental Manuscripts (MSS), numbers: 1112, 1122, 1598 Gemeentearchief, Stadsarchief, number: 1280

Lewis, B. (1968), The Emergence of Modern Turkey, London.

Mantran, R. (1990), XVI-XVII. Yüzyillarda Osmanli Imparatorluğu, M.A. Kiliçbay (trans.), Ankara.

Mantran, R. (1988), "XVII. Yüzyilin İkinci Yarisinda Doğu Akdenizde Ticaret, Deniz Korsanliği ve Gemiler Kafileleri ," Belleten, 690-707.

Masson, P. (1896), Histoire du commerce francais dans le Levant au XVIIe siècle, Paris.

Masters, B. (1988), The Origins of Western Economic Dominance in the East: Mercantilism and the Islamic Economy in Aleppo, 1600-1780, New York. 
Journal of Al-Tamaddun, Vol. 15 (1), 2020, 13-30

Meilink-Roelofsz, M. A. (1962), Asian Trade and European Influence in the Indonesian Archipelago between 1500 and about 1630, The Hague.

Michael Talbot (2017), British-Ottoman Relations, 1661-1807: Commerce and Diplomatic Practice in Eighteenth-Century Istanbul, London: Boydell Press.

Millard, A. M. (1956), The Import of London, 1600-1640, PhD dissertation, University of London.

Pamuk, Ş. (1997), "Money in the Ottoman Empire, 1326 to 1914," in H. İnalcik \& D. Quataert (eds.), An Economic and Social History of the Ottoman Empire: The Ottoman Empire 1300-1914, Cambridge University Press.

Parry, V. J. (1970), "Materials of War in the Ottoman Empire," in M. A. Cook (ed.), Studies in the Economic History of the Middle East: From the Rise of Islam to the Present Day, Oxford University Press.

Posthumus, N. W. (1939), De Geschiedenis van de Leidsche Lakenindustrie, Gravenhage-Martinus Nijhoff.

Raven G. J. A. \& Rodger, N. A. M. (eds.) (1990), Navies and Armies: The Anglo-Dutch Relationship in War and Peace 1688-1988, Edinburgh.

Refik, A. (1988), Onikinci Asr-i Hicride İstanbul Hayati 1590-1785, Istanbul.

Rosedale, R. H. G. (1904), Queen Elizabeth and Levant Company, London.

Schefer, C. (1949), Antoine Galland, İstanbul'a ait Günlük Hatiralar (1672 -1673), N. S.Orik (trans.), Ankara.

Setton, K. M. (1991), Venice, Austria, and the Turks in the Seventeenth Century, The American Philosophical Society Press.

Smith, A. (1993), An Inquiry into the Nature and Causes of the Wealth of Nations, K. Sutherland (ed.), New York: Oxford University Press.

Steensgaard, N. (1973), The Asian Trade Revolution of the Seventeenth Century: The East India Companies and the Decline of the Caravan Trade, University of Chicago Press.

Ülken, Y. Z. (1966), Türkiye'de Çağdaş Düşünce Tarihi I, Konya: Selçuk Press.

Wood, A. C. (1964), A History of the Levant Company, London.

Yücel, Y. (ed.) (1974), Kitab-i Mustetab, Ankara. 